\title{
SOME BIOLOGICAL PROPERTIES OF BULL SEMINAL VESICLE ASPERMATOGENIC SUBSTANCE AND ITS EFFECT ON MICE*
}

\author{
J. MATOUŠEK, A. PAVLOK, J. DOSTÁL AND J. GROZDANOVIC̆ \\ Laboratory of Animal Physiology and Genetics, \\ The Czechoslovak Academy of Sciences, Liběchov, Czechoslovakia
}

(Received 2nd May 1972)

Summary. Injection of mouse testes with aspermatogenic substance (AS) isolated from bull seminal vesicle fluid inhibited sperm production and caused a decrease in the weight of the testes. Subcutaneous injections of AS also caused a decrease in testis weight, but spermatogenesis was only slightly affected.

Administration of AS (2 to $2.5 \mathrm{mg}$ ) to female mice 1 to 13 days after mating resulted in a highly significant decrease in the number of embryos. When concentrations of $12.5 \mu \mathrm{g} \mathrm{AS} / \mathrm{ml}$, or more, were present in the medium in which two-blastomere mouse embryos were incubated, further development was arrested in $100 \%$ of the embryos. In vivo, however, death of the embryos occurred only after nidation. Injection of AS into prepubertal males or females did not provoke any visible disturbances at the time, or later when sexual maturity was reached.

The presence of AS in the diluent had no effect on the sperm motility or sperm survival time of bull, ram, boar and rabbit spermatozoa or on the fructolysis of bull and ram spermatozoa.

Samples of AS showed no proteolytic, DNase, esterase, alkaline phosphatase, acid phosphatase or lactate dehydrogenase activities but had high RNase activity and AS was therefore named AS RNase. Incorporation of $\left[2-{ }^{14} \mathrm{C}\right]$ orotic acid into male mice injected with AS RNase made it possible to detect a significant reversible decrease of pyrimidine synthesis in testicular tissue. No decrease of RNA in liver and kidney tissue could be detected.

\section{INTRODUCTION}

Recent studies have been published on the aspermatogenic effect of bull seminal vesicle fluid in heterologous males (Matoušek, 1966, 1967, 1969) and the effect was interpreted on an immunological basis. The existence of common or cross-reacting antigens of bull seminal vesicle fluid and of some cells in the spermatogenic epithelium of ram, rabbit and guinea-pig testes was pre-

- This paper reports on part of a project within the International Biological Programme. 
supposed. More recently, the results of studies of bull seminal vesicle fluid aspermatogenic effect in mice and chickens (Matoušek \& Petrovská, 1969) have cast doubt on the immunological hypothesis. Partial purification of the aspermatogenic substance (AS) and the sudden onset of degenerative changes in the seminiferous tubules following intratesticular injection of AS (Matoušek, Staněk \& Veselský, 1972) have strengthened the doubts concerning the antibody origin of the aspermatogenic effect. Observations of a very rapid antiembryonic process in mice caused by partially purified AS (Matoušek, 1973) have suggested a new hypothesis concerning its direct action. Further progress has only been made possible by the isolation and recognition of some of the properties of the substance (Dostál \& Matoušek, 1973).

This paper deals with the results of studies of the effect of isolated AS on mouse testes and embryos and of its enzymatic activity.

\section{MATERIALS AND METHODS}

Isolation of aspermatogenic substance from bull seminal vesicle fluid

Bull seminal vesicle fluid was collected from healthy sexually mature bulls at the slaughterhouse (Matoušek, 1969). The method of isolating AS from bull seminal vesicle fluid was described in a previous paper (Dostál \& Matoušek, 1973).

\section{Determination of aspermatogenic and antiembryonic effects of aspermatogenic substance}

The aspermatogenic effect of AS was studied on mice of the C57/BL and CBA strains. Male mice received (1) doses of 0.02, 0.04, 0.06, 0.08 and $0.1 \mathrm{mg}$ isolated $\mathrm{AS}$ suspended in $0.9 \% \mathrm{NaCl}(5 \mathrm{mg} \mathrm{AS} / \mathrm{ml})$ injected into the left testis (in every case, a similar dose was injected into four males); or (2) doses of 1.5 , 2.0 and $2.5 \mathrm{mg}$ AS in five subcutaneous injections administered over the course of 5 to 10 days.

The aspermatogenic effect was assessed by weighing (index weight) and histological investigation of the testes (Matoušek, 1969).

The antiembryonic effect of AS was studied in the same breeds of mice. Sexually mature females received injections of AS suspended in $0.9 \% \mathrm{NaCl}$ in doses of $0.5,1.0,1.5,2.0,2.5$ and $3.0 \mathrm{mg}$ in daily doses of $0.5 \mathrm{mg}$ at different times after mating. The time of mating was estimated from the finding of copulation plugs.

Mice injected on the 6 th day after the mating were killed with ether on the 10 th, 11 th or 12 th day after mating. Mice injected between the 7 th and 14 th days of pregnancy were killed 4 days after the last injection. The numbers of live or dead embryos were determined. Mice injected in the last quarter of the pregnancy were not killed. The embryonic mortality in these mice was assessed from the number of offspring born.

Sensitivity of mouse preimplantation and implantation embryos to aspermatogenic substance

Fertilized two-blastomere mouse embryos isolated after superovulation from the oviducts of females killed 42 to $44 \mathrm{hr}$ after injection of HCG (Praedyn, Spofa, Czechoslovakia) were used to study the effects of AS in vitro. Each culture 
unit consisted of a watch-glass $35 \mathrm{~mm}$ in diameter with $0.1 \mathrm{ml}$ medium containing twelve two-blastomere embryos under paraffin oil. The medium had the following composition: TCM 199, $70 \mathrm{ml}$; sodium bicarbonate $(1.32 \mathrm{~g} / 100 \mathrm{ml})$, $16 \mathrm{ml}$; sodium lactate, $0.225 \mathrm{~g}$; sodium pyruvate, $0.003 \mathrm{~g}$ made up to $100 \mathrm{ml}$ by tridistilled water. To $10 \mathrm{ml}$ of the stock solution, $0.03 \mathrm{~g}$ bovine serum albumin (Cohn Fraction V, Koch-Light, England) was added. The embryos were cultured at $37.5^{\circ} \mathrm{C}$, at a humidity of approximately $90 \%$ and in an atmosphere containing $95 \%$ air and $5 \% \mathrm{CO}_{2}$. The embryos were examined microscopically after $72 \mathrm{hr}$ in culture.

In a study of the effect of AS on the preimplantation development of embryos in vivo, female mice were injected with $2.5 \mathrm{mg}$ AS within 3 days of mating. The females were then killed 84 to $100 \mathrm{hr}$ after the expected time of ovulation and the ova were isolated by flushing the uterine horns with culture medium. Blastocysts were examined under an inverse microscope and by phase contrast.

The effect of AS on implantation was studied using twenty female mice which were injected with $2.5 \mathrm{mg}$ AS during the first 4 days after mating and were then killed 144 to $168 \mathrm{hr}$ after the expected time of ovulation. The number of implanted embryos was recorded. Sixteen control females were injected with $0.9 \% \mathrm{NaCl}$.

Effect of aspermatogenic substance on sperm motility, survival time and fructolysis

A solution containing $10 \mathrm{mg} \mathrm{AS} / \mathrm{ml}$ sodium citrate $\left(29 \mathrm{~g} \mathrm{Na}_{3} \mathrm{C}_{6} \mathrm{H}_{5} \mathrm{O}_{7}\right.$ $.2 \mathrm{H}_{2} \mathrm{O}$ in $1000 \mathrm{ml} \mathrm{H} \mathrm{H}_{2} \mathrm{O}$ ) was used for the dilution of twenty samples of bull ampullar spermatozoa, and the ejaculated spermatozoa of four rams, two boars and four rabbits, four drops of the solution being mixed with one drop of semen. The sperm concentration per $\mu \mathrm{l}$ of the bull and ram samples was $800 \times 10^{3}$ to $1000 \times 10^{3}$; that of the boar samples was $60 \times 10^{3}$ to $100 \times 10^{3}$ and that of the rabbit samples, $200 \times 10^{3}$ to $300 \times 10^{3}$. Sperm motility was evaluated on an arbitrary scale of 1 to 5 , the highest motility being designated by 5 . The percentage of motile spermatozoa was evaluated microscopically after 1, 3 and $24 \mathrm{hr}$.

The fructolysis of ampullar spermatozoa from two bulls and ejaculated spermatozoa from two rams was assessed according to the method described by Mann (1948). The spermatozoa were suspended in a solution containing $10 \mathrm{mg}$ $\mathrm{AS}$ and $10 \mathrm{mg}$ fructose/ml sodium citrate.

Effect of aspermatogenic substance on the sensitivity of bull ampullar spermatozoa to cold shock and haemolytic activity

The technique of Fulka, Sulcová \& Valenta (1965) was used to study the effect of AS on the sensitivity of the bull ampullar spermatozoa to cold shock. The spermatozoa were diluted by sodium citrate with or without the addition of $10 \mathrm{mg} \mathrm{AS} / \mathrm{ml}$ (and also diluted by the bull seminal vesicle fluid as a control for the cold-shock activity) and were rapidly cooled in a water bath to $0^{\circ} \mathrm{G}$. The motility of the cooled spermatozoa was evaluated on the arbitrary ' 1 to 5 ' scale.

For determination of the haemolytic activity of AS, the substance was dissolved in $0.9 \% \mathrm{NaCl}$ at concentrations of $5,10,20$ and $40 \mathrm{mg} / \mathrm{ml}$, and $0.05 \mathrm{ml}$ 
$2 \%$ bovine erythrocyte suspension was added to $0.1 \mathrm{ml}$ AS solution. For controls, the seminal vesicle fluid of different bulls diluted $0,1,2,4,8,16,32$ and 64 times by $0.9 \% \mathrm{NaCl}$ was used. The haemolytic reaction was evaluated after 2 and $4 \mathrm{hr}$ of incubation by the method described by Matoušek (1970).

\section{Oxidation and reduction cleavage of aspermatogenic substance}

The oxidation of AS using performic acid was carried out at $0^{\circ} \mathrm{C}$. For the reduction of AS, $\beta$-mercaptoethanol in $8 \mathrm{M}$-urea at laboratory temperature (18 to $21^{\circ} \mathrm{C}$ ) was used (Dostál \& Matoušek, 1973). Ribonuclease A from bovine pancreas ( $4 \times$ crystallized, Koch-Light, England) was used for comparison with AS.

Effect of aspermatogenic substance on body weight and numbers of red and white blood cells

Male and female mice of different age and body weight were injected with $2.5 \mathrm{mg} \mathrm{AS}$ at 5- or 10-day intervals. On the first day of the injection and once a week thereafter, the mice were weighed and the average value for each group was calculated.

Mice used for the blood cell determination were decapitated 4, 12, 18 or 33 days after the last injection of AS and blood samples were taken for determination of the numbers of red and white blood cells. Differential counts of 100 to 200 cells were made on smears stained with May-Grünwald's and Giemsa's stain.

\section{Assay of proteolytic activity}

Two 2-ml aliquots of $1 \%$ solutions of cattle haemoglobin in buffers of $\mathrm{pH}$ $4 \cdot 0,4 \cdot 5,5 \cdot 0,5 \cdot 5,6 \cdot 0,6 \cdot 5,7 \cdot 0,7 \cdot 5,8 \cdot 0,8 \cdot 5$ and $9 \cdot 0$, and an ionic strength of $0 \cdot 1$ (Miller \& Golder, 1950), were used for the assay. To one aliquot of each solution, $50 \mu \mathrm{l}$ of $0.1 \% \mathrm{AS}$ in water were added. After incubation for $15 \mathrm{~min}$ at $37^{\circ} \mathrm{C}, 4.5 \mathrm{ml} 0.3 \mathrm{~N}$-trichloracetic acid were added to precipitate protein. After a further incubation for $5 \mathrm{~min}$, the precipitate was filtered. The amount of the product was measured spectrophotometrically at $280 \mathrm{~nm}$, using haemoglobin solutions incubated without the enzyme as the controls.

Esterase, alkaline phosphatase, acid phosphatase and lactate dehydrogenase activities on disc electrophoresis

Disc electrophoresis $(7.5 \%$ acrylamide gel for electrophoresis at $\mathrm{pH} 9.4)$ carried out according to the methods described by Ornstein (1964) and Davis (1964) was chosen for the study of some specific activities of AS. The AS was applied in $0.3-\mathrm{mg}$ amounts to the acrylamide gel, which was $0.5 \times 8 \mathrm{~cm}$ in size.

Staining for esterase activity was performed using 0.15 M-phosphate buffer, $\mathrm{pH} 7 \cdot 2$, with Diazo Blue B salt and $\alpha$-naphthyl acetate according to the method of Veselský \& Kúbek (1970). The gels were incubated in the solution for 30 to $60 \mathrm{~min}$ at laboratory temperature.

The detection of alkaline phosphatase activity was carried out in $0.2 \mathrm{M}$-trishydrochloric acid buffer, pH 9.3, as described by Gomori (1948). Fast Blue $\mathrm{RR}$ salt and $\beta$-naphthyl sodium phosphate were dissolved in the buffer. The gels were incubated for 2 to $6 \mathrm{hr}$ at laboratory temperature. 
Acid phosphatase activity was detected by the procedure of Lawrence, Melnick \& Weiner (1960). The gels were incubated for 6 to $12 \mathrm{hr}$ at laboratory temperature in acetate buffer, $\mathrm{pH} 5.0$, with Fast Blue RR salt.

Lactate dehydrogenase activity was detected using $1 \mathrm{~m}$-sodium D-lactate, $\mathrm{pH}$ $7 \cdot 0$, according to the method described by Shaw \& Prasat (1970). The gels were incubated for $1 \mathrm{hr}$ at $37^{\circ} \mathrm{C}$.

\section{Assay of DNase activity}

The buffers, of $\mathrm{pH} 4 \cdot 0,5 \cdot 0,6 \cdot 0,7 \cdot 0$ and $8 \cdot 0$, and ionic strength $0 \cdot 1$, were prepared according to the method of Miller \& Golder (1950). The 0.1\% DNA (Koch-Light, England) solutions in the buffers with $0.01 \mathrm{M}-\mathrm{MgSO}_{4}$ were equilibrated to $37^{\circ} \mathrm{C}$, and $50 \mu \mathrm{l} 0.2 \%$ AS solution were added. After incubation for $5 \mathrm{hr}, 6.5 \mathrm{ml}$ methanol-acetic acid (12:1) solution were added to stop the reaction and precipitate DNA. Filtered supernatants were compared spectrophotometrically with the controls at $260 \mathrm{~nm}$.

\section{Assay of RNase activity}

Solutions $(0.1 \%$ and $1 \%)$ of yeast RNA (Serva) were made in buffers of $\mathrm{pH}$ $4 \cdot 0,4 \cdot 5,5 \cdot 0,5 \cdot 5,6 \cdot 0,6 \cdot 5,7 \cdot 0,7 \cdot 5,8 \cdot 0,8 \cdot 5$ and $9 \cdot 0$, and ionic strength $0 \cdot 1$ (Miller \& Golder, 1950). Two aliquots of the solution were equilibrated to $37^{\circ} \mathrm{C}$, and $10 \mu \mathrm{l}$ of $0.1 \% \mathrm{AS}$ dissolved in water was added to each. After incubation of the enzyme-substrate for $30 \mathrm{~min}, 6.5 \mathrm{ml}$ methanol-glacial acetic acid (12:1) were added to stop the reaction and to precipitate RNA. After a further incubation for $10 \mathrm{~min}$, the samples were filtered. Amounts of the enzymatic splitting product in the supernatants were measured spectrophotometrically at $260 \mathrm{~nm}$, using samples of RNA without enzyme as controls.

Incorporation of $\left[2-{ }^{14} C\right]$ orotic acid into male mouse testis, liver and kidney $R \mathcal{N} A$

A total of thirty-two male mice (weighing 24 to $30 \mathrm{~g}$ ) were injected with $2.5 \mathrm{mg}$ AS over 5 days $\left(0.5 \mathrm{mg}\right.$ AS in $0.1 \mathrm{~mJ} 0.9 \% \mathrm{NaCl} /$ day). The $\left[2-{ }^{14} \mathrm{C}\right]$ orotic acid $(10 \mu \mathrm{Ci} / 20 \mathrm{~g}$ body weight) was applied $1,4,6,8,15,37,44$ and 132 days after the last AS injection and, $2 \mathrm{hr}$ later, the mice were killed with ether. The RNA was isolated from the testes, kidney and liver by the method of Schmidt \& Thannhauser (1945). The amount of RNA was determined spectrophotometrically at $260 \mathrm{~nm}$. The activity of the samples was measured in liquid scintillators on an NZB 315 counter (Tesla, Prague). The values obtained were used for calculation of either the specific activity of RNA (ct $/ \mathrm{min} / \mathrm{mg}$ ) or the activity of the tissue $(\mathrm{ct} / \mathrm{min} / \mathrm{g}$ ). The average values for the groups of four mice were expressed as a percentage of the controls. The control animals were injected with $0.9 \% \mathrm{NaCl}$.

\section{RESULTS}

Effect of aspermatogenic substance on testicular and embryonic tissues

Intratesticular injections of bull seminal vesicle fluid AS resulted in an inhibition of spermatogenesis and a reduction in the weight of the testes. Using 
thirty sexually mature mice, the effective dose of AS (50\% reduction in testis weight and arrest of spermatogenesis) was found to be 0.06 to $0.08 \mathrm{mg}$.

Subcutaneous injections of AS also evoked a reduction in testis weight and partial disturbance of spermatogenesis, but large doses and a longer time were required. A $50 \%$ reduction in testis weight by the 21 st to the 42 nd day after the first AS injection and persistence of a statistically significantly lower weight until the 105th day could be evoked by a total of $2.5 \mathrm{mg}$ AS in five daily doses (Table 1).

Table 1. Influence of the aspermatogenic and antiembryonic substance on the testes of mice

\begin{tabular}{c|c|c|c}
\hline $\begin{array}{c}\text { No. of days after } \\
\text { the first injection } \\
\text { of } A S\end{array}$ & $\begin{array}{c}\text { No. of mice } \\
\text { injected }\end{array}$ & $\begin{array}{c}\text { Index weight } \\
\text { of both testes }\end{array}$ & $\begin{array}{c}\text { Degree of } \\
\text { histological damage }\end{array}$ \\
\hline Control $(0 \cdot 9 \% \mathrm{NaCl})$ & 15 & $7 \cdot 45 \pm 0 \cdot 71$ & 0 \\
7 & 12 & $5 \cdot 10 \pm 0 \cdot 50^{* *}$ & 0 to 1 \\
14 & 10 & $4 \cdot 12 \pm 0 \cdot 42^{* *}$ & 0 to 2 \\
21 & 10 & $3 \cdot 40 \pm 0 \cdot 46^{* *}$ & 0 to 2 \\
28 & 8 & $3 \cdot 45 \pm 0 \cdot 74^{* *}$ & 0 to 1 \\
35 & 6 & $3 \cdot 44 \pm 0 \cdot 39^{* *}$ & 0 \\
42 & 6 & $3 \cdot 57 \pm 0 \cdot 61^{* *}$ & 0 \\
49 & 5 & $3 \cdot 91 \pm 0 \cdot 59^{* *}$ & 0 \\
56 & 5 & $4 \cdot 30 \pm 0 \cdot 31^{* *}$ & 0 \\
84 & 5 & $4 \cdot 12 \pm 0 \cdot 58^{* *}$ & 0 \\
105 & 6 & $4 \cdot 69 \pm 0 \cdot 82^{* *}$ & 0 \\
\hline
\end{tabular}

$\mathrm{AS}=$ aspermatogenic substance.

** Statistically highly significant, $P<0.01$.

$\dagger 0=$ normal histological appearance; $i=$ complete disappearance of intratubular spermatozoa; 2 = desquamation of spermatogenic layers.

Table 2. Embryonic mortality in mice after injections of the aspermatogenic and antiembryonic substance

\begin{tabular}{|c|c|c|c|c|c|}
\hline \multirow{2}{*}{$\begin{array}{l}\text { No. of days } \\
\text { from the } \\
\text { mating to } \\
\text { the first } \\
\text { injection of } A S\end{array}$} & \multirow{2}{*}{$\begin{array}{l}\text { No. of } \\
\text { females } \\
\text { injected }\end{array}$} & \multicolumn{2}{|c|}{$\begin{array}{l}\text { No. of pregnant } \\
\text { females }\end{array}$} & \multicolumn{2}{|c|}{ No. of embryos per } \\
\hline & & Total & Percentage & $\begin{array}{l}\text { pregnant } \\
\text { female }\end{array}$ & $\begin{array}{c}\text { injected } \\
\text { female }\end{array}$ \\
\hline $\begin{array}{c}\text { Control } \\
(0 \cdot 9 \% \mathrm{NaCl}) \\
1 \text { to } 4 \\
6 \text { to } 10 \\
11 \text { to } 13 \\
15 \text { to } 17\end{array}$ & $\begin{array}{l}26 \\
51 \\
25 \\
22 \\
14\end{array}$ & $\begin{array}{r}22 \\
6 \\
4 \\
3 \\
13\end{array}$ & $\begin{array}{l}84 \cdot 61 \\
11 \cdot 76^{* *} \\
16 \cdot 0 * * \\
16 \cdot 66^{* *} \\
92 \cdot 85\end{array}$ & $\begin{array}{l}6 \cdot 59 \pm 1 \cdot 72 \\
5 \cdot 00 \pm 1 \cdot 33 \\
5 \cdot 75 \pm 1.50 \\
6.33 \pm 0.44 \\
6.69 \pm 1.54\end{array}$ & $\begin{array}{l}5.57 \pm 2.50 \\
0.59 \pm 1.03 * * \\
0.92 \pm 1.50 * * \\
0.86 \pm 1.48 * * \\
6.21 \pm 1.92\end{array}$ \\
\hline
\end{tabular}

AS = aspermatogenic substance. Aspermatogenic substance was injected in a dose of $0.5 \mathrm{mg} /$ day over 4 days.

** Statistically highly significant, $P<0 \cdot 01$.

We were unable to find a minimal amount of AS which, when injected subcutaneously into pregnant female mice, would provoke total embryonic mortality. From doses of 0.5 to $3 \mathrm{mg} \mathrm{AS}$ applied within 3 to 5 days, a total of $2 \mathrm{mg}$ injected in daily doses of $0.5 \mathrm{mg}$ seemed to be optimal. The reduction of embryo or offspring numbers was statistically highly significant when this amount of 
AS was injected within the 1st to 13th day after mating. After the 15th day, it was ineffective (Table 2).

The development of 108 mouse embryos at the two-blastomere stage was completely arrested at the four-blastomere or morula stage when they were incubated with $12 \cdot 5,25,50$ or $100 \mu \mathrm{g} \mathrm{AS} / \mathrm{ml}$ medium. Of 108 mouse embryos at the two-blastomere stage which were used as controls, ninety-three developed into blastocysts. In a further experiment, $6.25 \mu \mathrm{g} \mathrm{AS} / \mathrm{ml}$ medium were found to prevent further development to the blastocyst stage in thirty-four out of fortyeight embryos while development to the blastocyst stage continued in thirtyseven out of forty-eight embryos incubated in control medium. Partial inhibition of the development of the two-cell embryos by $6.25 \mu \mathrm{g}$ AS was statistically significant $(P<0.0025)$.

No activity was demonstrated in either oxidized or reduced AS samples. Using $100 \mu \mathrm{g}$ oxidized $\mathrm{AS}$ in $1 \mathrm{ml}$ medium for the culture of twenty-four twocell embryos, twenty-one of them developed to blastocysts, while, in the control medium, twenty-two blastocysts developed from twenty-four two-cell embryos. Using $100 \mu \mathrm{g}$ reduced $\mathrm{AS}$ in $1 \mathrm{ml}$ medium, eleven blastocysts developed both from twelve experimental and from twelve control embryos. By contrast, AS heated to $100^{\circ} \mathrm{C}$ for $120 \mathrm{~min}$ at $\mathrm{pH} 4.0$ was almost normally active. The cleavage of embryos was inhibited by $12.5 \mu \mathrm{g}$ heated AS. Only four blastocysts developed from twenty-four two-cell embryos exposed to heat-treated AS, and $25 \mu \mathrm{g} / \mathrm{ml}$ or more of heat-treated AS completely inhibited blastocyst development.

No marked effect on embryo development at the preimplantation stage was observed when AS, in a dose of $2.5 \mathrm{mg} /$ mouse, was injected into twelve female mice within 3 days of mating. Sixty-four embryos which had developed to the blastocyst stage (5.33/female) were obtained 84 to $100 \mathrm{hr}$ after mating. Thirtynine blastocysts $(9 \cdot 75 /$ female) were obtained from four mice which had received $2.5 \mathrm{mg}$ AS 7 to 11 days before superovulation.

The same doses of AS injected into female mice within 4 days of mating resulted in a decrease in the number of implanted embryos estimated 144 to $168 \mathrm{hr}$ after mating. Of twenty AS-treated females, only four were pregnant with a total of twenty-six implanted embryos. Of the sixteen females in the control group, twelve were found to be pregnant and a total of eighty-four implantations were detected. The difference between experimental and control groups was statistically highly significant.

Injections of AS into mice before sexual maturity did not appear to cause any disturbance at the prepubertal, pubertal or postpubertal stage. At 14 days' gestation in seventeen females which were injected with $2.5 \mathrm{mg}$ AS when their body weight was 6 to $10 \mathrm{~g}$ and mated when they reached 20 to $22 \mathrm{~g}$, the average number of embryos was $6 \cdot 47 \pm 3 \cdot 17$. Eight males, each weighing between 8 and $10 \mathrm{~g}$, were injected with the same doses of AS as the females. When they reached sexual maturity, they were mated with thirty-six females. The average number of embryos recorded per female impregnated by a particular male ( $5 \cdot 33 \pm 3.02)$ compared with that in the foregoing experiment is indicative of no effect on male fertility.

Injections of AS had no effect on the ratio of males and females in litters. In a 
total of 168 offspring from twenty-three females injected with AS at different stages of pregnancy, there were eighty-two females and eighty-six males.

Effect of aspermatogenic substance on motility, vitality and fructolysis of spermatozoa

Aspermatogenic substance present in the medium for dilution of bull ampullar spermatozoa and ejaculated bull, boar and rabbit spermatozoa had no effect on the motility or sperm survival time. Head-to-head agglutination was occasionally observed in rabbit spermatozoa. The fructolysing ability of bull ampullar and ram ejaculated spermatozoa remained unchanged and also the sensitivity of bull ampullar spermatozoa to cold shock. Since AS does not haemolyse homologous erythrocytes, it cannot be regarded as the same substance as the haemolytic factor of bull seminal vesicle fluid.

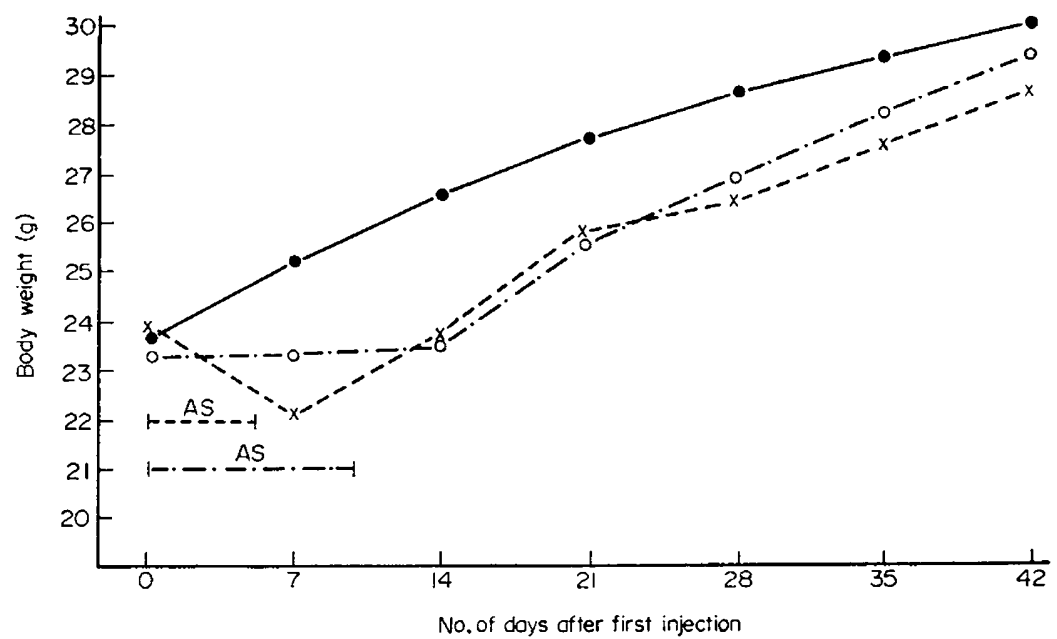

TEXT-FIG. 1. The effect of injections of aspermatogenic substance on male mice. The control group ( $\bullet$ consisted of twenty mature males. One experimental group $(x)$ consisted of thirty mature males injected daily with $0.5 \mathrm{mg}$ AS for 5 days. A second experimental group $(O)$ consisted of twenty mature males injected with $0.5 \mathrm{mg}$ AS every 2 nd day over a period of 10 days. AS $=$ times of the aspermatogenic-substance injections.

Influence of aspermatogenic substance on body weight and the numbers of red and white blood cells

The body weight of sexually mature mice (weighing at least $20 \mathrm{~g}$ ) injected daily with $0.5 \mathrm{mg}$ AS for 5 days decreased by an average of $7.5 \%$ in thirty males (Text-fig. 1) and $4 \%$ in twenty-two females $(P<0.01)$. Both these groups regained the body weight of the beginning of the experiment after 2 to 3 weeks. Statistically significantly lower body weights for the mice in the experimental groups compared with those in the control group were observed till the 35 th day.

The same AS doses decreased the body weight of ten males when injected shortly before sexual maturity $(15 \mathrm{~g})$. These mice regained their original weight in a shorter time than those in the previous experiment. By the 21 st day after the first AS injection, the mice in the experimental group had almost the same body weight as those in the control group (Text-fig. 2). 


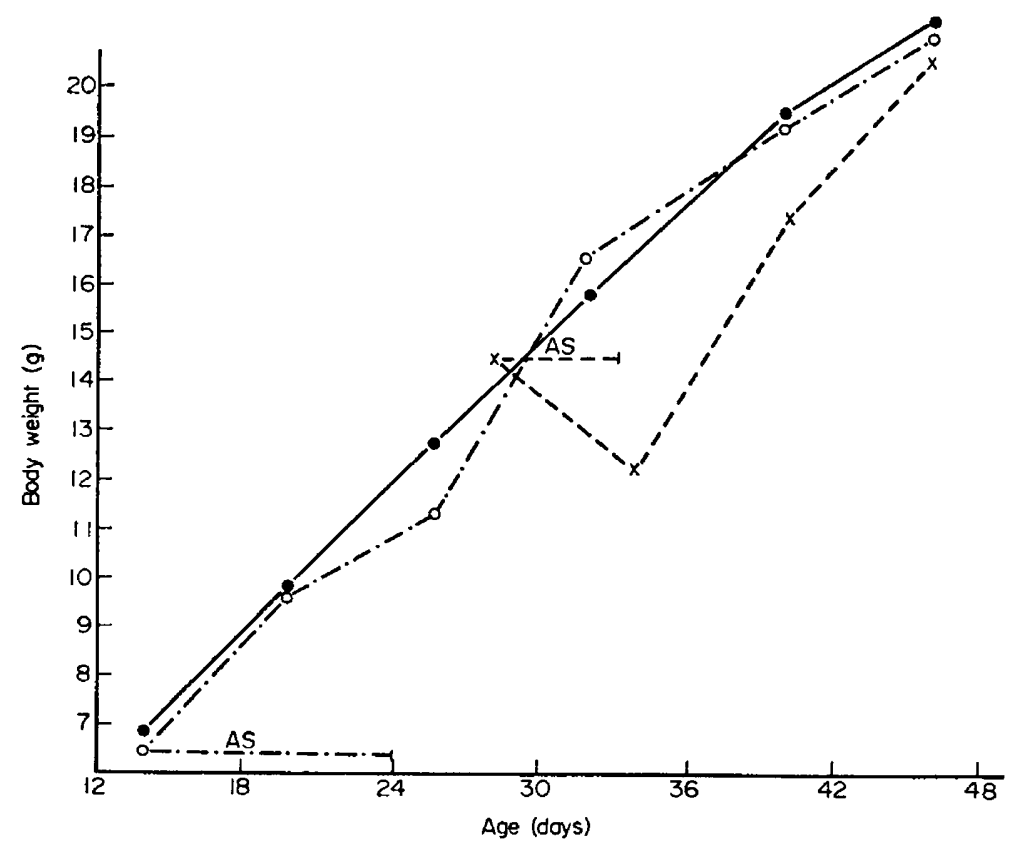

Text-pIG. 2. Average daily gain of male immature mice. The control group ( $\bullet$ ) consisted of eighteen immature males. One experimental group $(x)$ consisted of ten immature males injected daily with $0.5 \mathrm{mg}$ AS for 5 days. A second experimental group (0) consisted of twelve immature mice injected with $0.5 \mathrm{mg}$ AS every 2 nd day over a period of 10 days. AS = times of the injections of aspermatogenic substance.

When the total dose of AS (2.5 mg) was distributed over a 10-day period, the growth of the mature male mice showed no increase (Text-fig. 1) but remained practically unchanged in the immature mice (Text-fig. 2).

The numbers of red and white blood cells were unchanged both in males and females. The only change detected was a significant rise in the percentage of

Table 3. Blood cell determination after injections of aspermatogenic substance into mice

\begin{tabular}{|c|c|c|c|c|}
\hline $\begin{array}{l}\text { No. of days after last } \\
\text { injection of } A S\end{array}$ & $\begin{array}{l}\text { No. of } \\
\text { mice }\end{array}$ & $\begin{array}{c}\text { No. of red } \\
\text { cells } \times 10^{3} / \mu l\end{array}$ & $\begin{array}{l}\text { No. of white } \\
\quad \text { cells } / \mu l\end{array}$ & $\begin{array}{l}\text { Percentage of heterophils } \\
\text { in differential white } \\
\text { blood cell counts }\end{array}$ \\
\hline $\begin{array}{l}\text { MaLES } \\
\text { Controls } \dagger\end{array}$ & 16 & $5727 \pm 437$ & $3321 \pm 1840$ & $30 \cdot 43 \pm 6 \cdot 06$ \\
\hline $\begin{array}{l}4 \text { days } \\
18 \text { days } \\
33 \text { days }\end{array}$ & $\begin{array}{r}11 \\
11 \\
7\end{array}$ & $\begin{array}{l}5340 \pm 600 \\
6099 \pm 432 \\
6334 \pm 1041\end{array}$ & $\begin{array}{l}2636 \pm 880 \\
3736 \pm 1650 \\
3057 \pm 1221\end{array}$ & $\begin{array}{l}46 \cdot 09 \pm 7 \cdot 54 * * \\
28 \cdot 81 \pm 7 \cdot 63 \\
33 \cdot 40 \pm 8 \cdot 40\end{array}$ \\
\hline $\begin{array}{l}\text { FEMALES } \\
\text { Controls } \dagger \\
\text { Exp. animals }\end{array}$ & 21 & $5668 \pm 611$ & $2562 \pm 856$ & $20 \cdot 76 \pm 7 \cdot 57$ \\
\hline $\begin{array}{l}4 \text { days } \\
12 \text { days }\end{array}$ & $\begin{array}{l}32 \\
19\end{array}$ & $\begin{array}{l}6119 \pm 786 \\
5458 \pm 857\end{array}$ & $\begin{array}{l}2186 \pm 711 \\
1963 \pm 528\end{array}$ & $\begin{array}{l}25 \cdot 53 \pm 8 \cdot 87 \\
21 \cdot 57 \pm 7 \cdot 21\end{array}$ \\
\hline
\end{tabular}

AS $=$ aspermatogenic substance. $\dagger$ Determined 12 days after injection of $0.9 \% \mathrm{NaCl}$.

** Statistically highly significant, $P<0 \cdot 01$. 
heterophils in a differential white cell count on the 4th day after injection of AS (Table 3). At a later stage in the males and over the whole experimental period in the females, no other major differences were detected compared with the controls.

\section{Enzymatic activity of the aspermatogenic substance}

The samples of AS did not show proteolytic, DNase, esterase, alkaline phosphatase, acid phosphatase or lactate dehydrogenase activities, but had high RNase activity (Text-fig. 3 ).

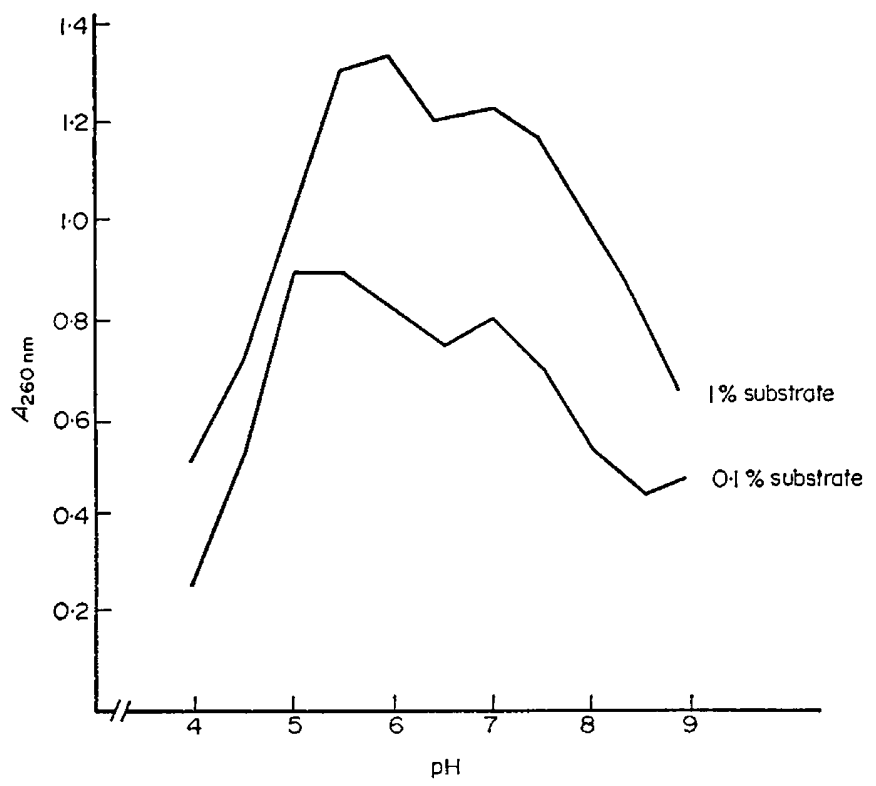

TEXT-pig. 3. Effect of $\mathrm{pH}$ on the ribonuclease activity of aspermatogenic substance. Yeast RNA (Serva) was used as the substrate.

Incorporation of $\left[2-{ }^{14} C\right]$ orotic acid into the $R \mathcal{N} A$ of testis, liver and kidney of mice injected with $A S$

The incorporation of $\left[2-{ }^{14} \mathrm{C}\right]$ orotic acid in male mice injected with AS at different time intervals resulted in a rapid decrease in the synthesis of pyrimidine in the testes shortly after the application of AS. The lowest specific activity of RNA in the testes was observed from the 7th to 23rd day after the last AS injection. This was followed by a gradual return to the normal level (Text-fig. 4). In liver and kidney, a slight increase was observed in the RNA activity.

Comparison of the activity of aspermatogenic substance with that of pancreatic $R \mathcal{N}$ ase $A$

Injection of pancreatic RNase A into the testes of ten mice and subcutaneous injection of the enzyme into sixteen male mice did not evoke any aspermatogenic effect. Injection of $2.5 \mathrm{mg}$ pancreatic RNase A into fifteen female mice 3 to 6 days after mating had no effect on the number of embryos observed on the 
14th day of pregnancy $(6 \cdot 06 \pm 2 \cdot 2$ /female). Pancreatic RNase A in either 50 - or $100-\mu \mathrm{g}$ doses did not prevent the development of twenty-four two-cell mouse embryos.

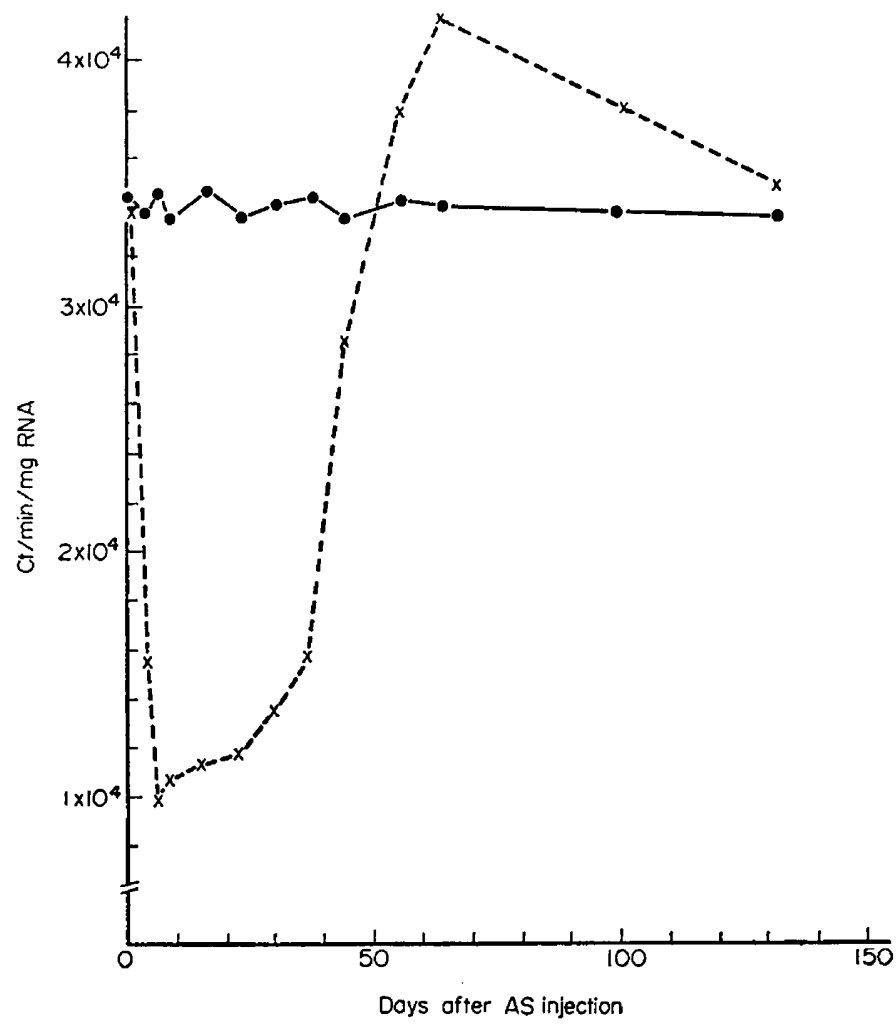

TeXT-FIG. 4. Specific activity of testicular RNA ([2-14 $\mathrm{C}]$ orotic acid incorporation) on various days after AS injection. $\bullet$, The control group of mice; $x$, the experimental group of mice.

\section{DISCUSSION}

The difference between the complete inhibition of spermatogenesis in the mouse after intratesticular injection of AS and the partial inhibition of spermatogenesis, together with a significant decrease in the testicular weight, after subcutaneous injection of AS can be explained in several ways. Following subcutaneous injection, AS is distributed to the whole body and the effective dose in the testes is probably lower than when AS is injected directly into the testis. The formation of antibodies against AS as well as the existence of testis barrier mechanisms might affect the inhibition of spermatogenesis.

Barrier mechanisms may also be responsible for the resistance of some embryos to AS. The barrier protection to the embryo apparently depends mainly on the mother. This supposition is based on the average number of embryos produced by pregnant mice injected with AS (Table 2) and gives rise to the hypothesis that the effect of AS on embryogenesis in the mouse is governed by the law of 'all or nothing'. 
From the results presented in this paper, it is evident that the development of embryos in vitro can be blocked by AS from the four-cell to the morula stage, but suppression of embryo development in vivo takes place after nidation. It seems that up to the implantation period, some barrier protection of the embryos exists.

An interesting feature is the resistance of embryos to AS during the last quarter of pregnancy. Barrier mechanisms can again be considered and a sudden decrease in the sensitivity of the embryo tissues to AS seems to be a plausible explanation. This hypothesis would explain some of our unpublished results using high doses of AS ( $5 \mathrm{mg} /$ mouse) which evoke embryonic mortality even in the last days of pregnancy.

The fact that AS activity appears to be specifically directed against the testicular and embryonic tissues while having little damaging effect on other tissues and metabolic processes is apparent from the results of the experiments dealing with the effects of AS on prepubertal mice. Young male and female mice in the prepubertal stage did not respond to two to three times the dose which was effective in the adult mouse (calculated per $\mathrm{g}$ body weight). The body weight of mice which decreased following daily injections of AS returned to original levels within a few days. The theory that AS might be effective as a common cytostatic agent which was considered by Matoušek (1969) is not supported by the results of the present study. Unlike the response in female mice described by Matoušek (1973), decreasing numbers of leucocytes were not found when AS was injected into either male or female mice.

The mechanism of the effect of AS on testicular and embryonic cells of mice and other animals (Matoušek, 1969; Matoušek \& Petrovská, 1969) has been substantially elucidated by the discovery of the ribonuclease activity of AS. From the comparative experiments with bovine pancreatic RNase A, however, it is evident that AS RNase has specific effects which pancreatic RNase A has not, and the enzymes have different molecular weights. The most interesting difference lies in the biological effects of the two enzymes on the cells of testes and embryos, even when the substrate specificities of both the ribonucleases tested using thirty-six natural and synthetic substrates of purine and pyrimidine character (Holý \& Grozdanovic, 1972) were shown to be almost identical.

A report of the presence of ribonuclease in bull seminal plasma was published by D'Alessio \& Leone (1963), and Floridi \& D'Alessio (1967) achieved its isolation. Bovine seminal ribonuclease was prepared in crystalline form by Floridi (1968), who also found that antibodies prepared against crystalline seminal ribonuclease did not cross-react with pancreatic RNase A. Further isolation of the seminal ribonuclease, this time from the seminal vesicle tissue of bulls, was published by Hosokawa \& Irie (1970). The kinetic study of its reaction was described by Irie \& Hosokawa (1971). It seemed likely that AS RNase might be identical with the ribonuclease isolated by Floridi \& D'Alessio (1967). There are, however, certain differences not only in the material used for RNase isolation (seminal plasma, seminal vesicles) and in the isolation procedure, but also in molecular weight. The molecular weight of AS RNase is 22,000 (monomer) at $\mathrm{pH} 9.1$ or higher, and 44,000 (dimer) at $\mathrm{pH} 5.5$ or lower. At $\mathrm{pH} 7.6$, Dostál \& Matoušek (1973) determined the molecular weight of AS RNase as 
29,000. Floridi (1968) and Hosokawa \& Irie (1970) determined the molecular weight of seminal RNase as 25,500 at $\mathrm{pH} 7 \cdot 5$. The biological effects of seminal RNase were not described by any of these authors and it is, therefore, not possible to arrive at a final decision about the identity of these enzymes.

From the results of the study involving the incorporation of $\left[2-{ }^{14} \mathrm{C}\right]$ orotic acid (precursor in the synthesis of pyrimidine nucleotides), it is evident that in mouse testes, a rapid decrease of pyrimidine synthesis occurs and a similar decrease was found in the embryos (unpublished results). The decrease of RNA activity does not, however, occur in the liver and kidney of mice injected with AS RNase though the enzyme does have some slight effect on other tissues as can be concluded from the results showing a decrease in the body weight of injected mice.

Although the mechanism of the action of AS RNase is at present unknown, we are testing a working hypothesis concerning the differences of some specific tissue inhibitors.

\section{ACKNOWLEDGMENTS}

The authors express their thanks to Mr V. Pech, Dr F. Zavřel and Miss J. Janatková for technical collaboration.

\section{REFERENCES}

D'Alessio, G. \& LeOne, E. (1963) The action of seminal enzymes on ribonucleic acid. Biochem. 7. 89, $183(7 \mathbf{P})$.

DAvis, B. T. (1964) Disc electrophoresis. II. Method and application to human serum proteins. Ann. N.Y. Acad. Sci. 121, 404.

Dostál, J. \& MAtoušEK, J. (1973) Isolation and some chemical properties of aspermatogenic substance from bull seminal vesicle fluid. 7. Reprod. Fert. 33, 263.

Floridi, A. (1968) Grystalline ribonuclease from bull semen. Biochem. biophys. Res. Commun. 32, 179.

Floridr, A. \& D'Alessio, G. (1967) Compartamento cromatografico della ribonucleasi seminale. Boll. Soc. ital. Biol. sper. 43, 32.

Fulka, J., Sulcová, H. \& Valenta, M. (1965) Protein polymorphism of the seminal vesicle of bulls. In: Proc. 9th Europ. Conf. Anim. Blood Grps, Prague 1964, p. 381. Ed. J. Matoušek. Publishing House of the Czechoslovak Academy of Sciences, Prague.

Gomori, G. (1948) Histochemical differentiation between esterases. Proc. Soc. exp. Biol. Med. 64, 4.

HolÝ, A. \& Grozdanovič, J. (1972) The substrate specificity of bovine seminal vesicle fluid ribonuclease (ribonuclease AS). Biochim. biophys. Acta, 277, 556.

Hosokawa, S. \& IRIE, M. (1970) Purification and properties of seminal vesicle ribonucleases. $\mathcal{F}$. Biochem., Tokyo, 69, 683.

Irie, M. \& HosokaWA, S. (1971) Kinetic studies of ribonucleases from bovine seminal vesicles. $\mathcal{F}$. Biochem., Tokyo, 70, 301.

Lawrence, S. H., Melnick, P. S. \& Weiner, H. E. (1960) A species comparison of serum proteins and enzymes by starch gel electrophoresis. Proc. Soc. exp. Biol. Med. 105, 572.

ManN, T. (1948) Fructose content and fructolysis in semen. Practical application in the evaluation of semen quality. F. agric. Sci., Camb. 38, 323.

Matoušex, J. (1966) Antigenicity of the seminal vesicle fluids in bulls. In: Proc. 10th Europ. Conf. Anim. Blood Grps, Paris, p. 523. Institut National de la Recherche Agronomique, Institut Pasteur de Paris.

MAToušEx, J. (1967) Antigenicity of the seminal vesicle fuids in bulls (aspermatogenic, spermatozoa cold shock sensitizing and hemolytic substances). In: Proc. Int. Symp. Immun. Spermatozoa and Fertilization, Varna, p. 135. Ed. K. Bratanov. Bulgarian Academy of Sciences Press, Sofia.

MAToušEk, J. (1969) Effects on spermatogenesis in guinea-pigs, rabbits and rams after their immunisation with sexual organ fluids of bulls. 7 . Reprod. Fert. 19, 63.

Matoušek, J. (1970) Haemolytic factor in bovine seminal vesicle fluid. I. Individual differences in the sensitivity of cattle erythrocytes. Anim. Blood Groups $\mathscr{E}$ biochem. Genet. 1, 89. 
MatouŠEK, J. (1973) Antiembryonic effect of bull seminal vesicle fluid in mice. F. Reprod. Fert. 32, 175.

Matoušek, J. \& PetrovskÁ, E. (1969) Antifertilizing effect of the seminal vesicle fluid of bulls on females. F. Reprod. Fert. 20, 189.

Matoušek, J., StanĚk, R. \& Veselskŕ, L. (1972) First attempt to characterize an aspermatogenic substance in the seminal vesicle fluids of bulls. 7. Reprod. Fert. 29, 179.

Miller, G. L. \& Golder, R. H. (1950) Buffers of pH 2-12 for use in electrophoresis. Atchs Biochem. 29, 420.

Ornstein, L. (1964) Disc electrophoresis. I. Background and theory. Ann. N.Y. Acad. Sci. 121, 366.

Schmidr, G. \& Thannhauser, S. J. (1945) A method for the determination of desoxyribonucleic acid, ribonucleic acid and phosphoproteins in animal tissues. F. biol. Chem. 161, 83.

Shaw, C. R. \& Prasat, R. (1970) Starch gel electrophoresis of enzymes-a compilation of recipes. Biochem. Genet. 4, 297.

Veselskx́, L. \& KúBEK, A. (1970) Immunoelectrophoretic study of esterase in blood serum, spermatozoa and genital tract fluid of bulls. Anim. Blood Groups $\mathcal{E}$ biochem. Genet. 1, 95. 